\title{
"Red Light" in Chile: \\ Parents Participating as Consumers \\ of Education Under Global Neoliberal Policies
}

\author{
Verónica López, Romina Madrid and Vicente Sisto
}

Additional information is available at the end of the chapter

http://dx.doi.org/10.5772/50305

\section{Introduction}

International research has provided evidence of a connection between the construction of collaborative alliances between parents and schools and the improvement of educational quality. In Chile, parent participation has been included as one of several aspects of community participation in the educational reforms of the last two decades. In this chapter, we analyze several Chilean educational policies that promote parent participation, based on three underlying logics or conceptions of education: the neo-liberal project of education, the civil-rights movement in education, and the emancipatory approach to education (Reca \& López, 2001). These different logics promoted by educational policies for parental participation in education have been mixed, in the sense that one policy may contain two of these logics. We provide evidence based on empirical studies about parent participation, providing an account of the tensions produced between orientations stemming from educational policies and the educational actors that provide meaning to, transform - and in some cases reproduce - the proposed logic.

Following Apple $(2004,2010)$ and Gordon and Nocon (2008), we hold that globalization policies have predominantly installed the logic of neoliberalism. Neoliberal policies and practices are characterized as those strongly promoting private property rights, promoting free trade and free markets. Research on the effect of globalized neoliberal policy in education has depicted a higher segregation and stratification in neoliberal-practicing societies. We argue that neoliberal global policies subjectivize parents as consumers of education, and promote individual forms of parent participation through one dominant mode: school choice.

But, in Chile, parents have been subjectivized as consumers of education since the military dictatorship in the early 1980s, before globalization policies became increasingly dominant. 
Parent school choice was a policy installed in Chile by the military dictatorship which radically changed the educational system following a neoliberal, market-driven approach. In this chapter, we argue that globalization policies have helped to strengthen a type of parent participation in education, which focuses on their role as consumers. This means that one type of logic has prevailed over others.

In Chile, the "neoliberal experiment" created during the military dictatorship and preserved after the return to democracy, installed a neoliberal logic underlying economic, social, and educational policies (Fischer, González, \& Serra, 2006). The structural elements that characterize a Chilean educational system are market driven, so principles such as deregulation, competition, and stratification were expected to be applied by public schools (Barlett et al, 2002). In Chile, this translated into the expansion of private schools by making them eligible for public funding, the introduction of market instruments to promote competitive behavior between the publicly funded schools; the use of vouchers; the collection of tuition fees; and the deployment of an extended range of opportunities for families to choose a school for their children (Bellei, 2007). Hence, it assumes parental school choice is an instrument consistent with the freedom to choose logic (Friedman, 1962).

The first major policy installed by the military dictatorship was the privatization of public schools through joint "public+private ventures", known as public-subsidized schools ("colegios particulares subvencionados"). These schools are administered by the private sector and funded partly by the State and partly by the student's family. The second policy was the creation, in 1981, of a large-scale voucher system, where the State finances publicmunicipal and public-subsidized schools through a funding policy based on student attendance records. Vouchers are not given to the student or his/her family but to schools, so that schools need to "compete" for student enrollment. A third policy was the introduction of a standards-based, high-stakes national assessment of educational achievement, the SIMCE test. These policies have installed a scheme where parental choice is understood as THE motor that can "rationally" improve education in a free-market scenario, where parents are assumed to be in a position to choose what they perceive to be the best school for their children. This context defines the role of parents mainly as decision targets, that is, as customers, who are able to choose the educational institution that best suits their needs based on information that is publicly available. As Montecinos, Sisto and Ahumada (2010) pose, "from a demand perspective, increased privatisation purports to promote and affirm parents' rights and individual responsibility in choosing a school. Theoretically, giving the parents the right to choose will increase quality because they will choose a school that shows good academic results and schools will make an effort to retain the fidelity of the parents" (p. 489).

The "Concertación", the center-and-left wing political coalition which governed the country from 1990 up to the year 2010, proposed a hybrid, mixed approach of neoliberal and human rights-based approach, combining both political community and market-driven models in their approach (Ministerio de Educación, 2002; Ministerio de Educación/CIDE/UNICEF, 2005). During the decade of 1990s and beginning of the XXI century, parents were invited to participate in the school system as organized citizens through local and regional Parent Associations (Bellei, Gubbins, \& López, 2002) but also as consumers of education through a 
school choice policy that was maintained during this decade from the military dictatorship (Martinic, 2002).

In this chapter, we take a close look at different forms of parent participation in the Chilean school system during the last decade, organizing these different forms based on the logic underlying them: Are parents invited to participate as consumers of education, citizens or agents of social transformations? Are they invited to participate in all of these forms? Which one of them is most dominant? We establish a relationship between different programs and actions oriented towards different types of parent participation, based on these three underlying conceptions.

\section{Parent involvement: Global views, local views}

The international literature shows that educational policymakers and teachers across the world agree that the involvement of parents enhances the academic success of students (Epstein, 2001; Pomerantz, Moorman, \& Litwack, 2007). Latin-American research has provided evidence of a positive relation between the construction of collaborative alliances between parents and schools, and the improvement of educational quality (Dabas, 2000; Martinic, 2002; Reca \& Avila, 1998; Mineduc, 2012). Flexibility and fluidness in the relationship between the members of the community and schools have been shown to constitute a factor of success in educational reforms (Reimers \& McGinn, 2000).

Alas, although parental involvement has reached the status of general consensus, research has shown that more involvement is not always better. In fact, Pomerantz \& Cols (2007) provide evidence that it is how parents become involved that largely determines the success of their involvement. They also argue that parent's involvement may matter more for some children than for others. The study of Fan \& Chen (2001), for instance, confirms that there is a moderate and practically meaningful relationship between parental involvement and academic achievement. Parental aspiration/expectation for children's education achievement has the strongest relationship, whereas parental home supervision has the weakest relationship with students' academic achievement. Likewise, the Abrahams and Gibss's (2002) study shows, parent involvement and practices of inclusion and exclusion should be related, since parents who are familiar with the language and style of educational discourse are more inclined to participate in their children's schooling. This can create a feeling of "inauthentic" or at least, non-authentic participation in terms of democracy (Anderson, 2001), since if middle-class, educated parents are usually the ones who take active part in organized forms of participation, they may do it in order to maintain or strengthen privileges for the middle-class students, thus making social stratification and segregation perpetual.

In this context, parental participation, in many other countries, is promoted as one of many forms of school improvement and has been included in many educational reforms in the United States, in Europe, and in Latin America (Anderson, 2001), specially due to decentralization efforts (Fernández-Soria, 1996). In Chile, parental participation has not only been included in the educational policy of co-existence, "Política Nacional de Convivencia" (Mineduc, CIDE, \& Unicef, 2005), but it is currently also part of the national school quality 
assessment system (i.e. SNED, Sistema Nacional de Evaluación de Desempeño). Schools that obtain high scores on this measure receive benefits in terms of material and human resources. Besides, in 2002, a specific policy called "Política de Participación de Padres, Madres y Apoderados en el Sistema Educativo" was created by the Ministry of Education. Today, parent participation is also mandatory for schools willing to apply for the Preferential School Subsidy Law (Ley SEP), which boosts government subsidy for students identified as "vulnerable" (i.e. coming from lower SES backgrounds) (Mineduc, CIDE, \& Unicef, 2005).

However, even though in Chile the post-dictatorial educational policies have recognized parental participation as an important aspect of school improvement, emphasis has been placed on different bearings of parent participation. According to Martinic (2002), although educational reforms require the participation of all actors in the interactions, communications, and responsibilities, in Chile a culture of non-participation prevails -deepened by the consequences of divergent social thinking during the military dictatorship- that affects their participation in school affairs:

"In spite of the importance granted in the discourses and policies, social participation is very difficult to achieve. In effect, people do not feel compelled to intervene in the public debate, nor are there formulas and techniques that guarantee a wide and permanent participation. The [Chilean] State's track record and the representations that the population have about its role are part of a culture that favors "delegation" over "shared responsibility" when facing services such as education. On the other hand, school cultures, the way in what teachers think, plus the lack of flexible and participatory methods to work together with families and communities, affect the generation of active spaces of cooperation and decision-making" (Martinic, 2002, p. 2) (translation and brackets are our own).

As we can see, parent participation in the school system is viewed as a difficult "task" that sparks resistance in the Chilean authoritarian culture, as well as in a non-participatory, authoritarian school culture. Developing stronger ties between parents and schools is a complex task, since these relationships mirror the contexts and inequitable power arrangements of the broader society. Nonetheless, reasons for promoting parent participation are value-laden and have to do with underlying educational views, which in turn delineate different conceptions of education and educational policies. Within each of these views, parent participation is promoted for different reasons and motives.

\section{The underlying logics of different forms of parent involvement}

Ten years ago we identified at least three of these educational approaches of parent involvement (Reca \& López, 2001): a) the neo-liberal project of education; b) the civil-rights movement in education; and c) the emancipatory approach to education.

Since the three logics were constructed following a weberian typology-scheme (Reca \& López, 2001), these "ideal types" are helpful in that they allow us to better understand the theoretical and epistemic nature of the discourses underlying parent participation. But, in real life, the different logics are intertwined, since the different forms and modes of parent participation 
cannot be lineally linked to one and only on logic. In other words, one mode of participation (for example school councils) can be traced back both to a civil-rights as well as to a transformational logic of education, depending on what type of school council we are talking about. In consequence, some of the logics of education delineated in this chapter may appear combined in the concrete day-to-day experiences of parents participating in education. This is particularly true for the civil-rights and transformational logics. In this section, we describe and provide updates for each of these approaches as they have evolved in Chile, and discuss how parent participation is visualized within each of these educational perspectives (see Figure 1).

\subsection{The neo-liberal project of education}

The neo-liberal approach poses parents as consumers and clients. Education is seen as a cost-effective enterprise, where schools compete with each other in order to obtain better educational results. The neo-liberal approach allocates responsibility on schools, which in turn deposit responsibility on teachers, parents, and students, thus tuning political and collective responsibility into an individual undertaking (Sisto, 2011). Neo-liberal reforms favor private endeavors, since schools are seen as able to compete against each other in a market-driven economy. Within this scenario, parents are client constructs, being responsible for consuming educational services. As consumers, they ought to be properly informed - hence the stress on standardized testing. They are perceived as capable of choosing the best educational options for their children, regardless of any other (economic, cultural) considerations. Parents are "free" to choose the best schools for their children, and this in turn feeds forward school improvement, since the "best schools" will prevail, and the "worst schools" will eventually be shut down (Elacqua, 2004; Torche, 2005).

The neo-liberal approach characterizes parents as consumers of products -in this case, of educational services - that the market has to offer, among which they have the right and freedom to choose, based on quality and preference criteria (selection based on school performance and on their own value-orientations). Parental participation in school administration and management is also promoted, since this is another form of expressing needs and approval/disapproval of the educational service being offered. Hence, parent participation is viewed as positive in terms of accountability (Reca \& López, 2001).

In the early 1980s, under the Pinochet regime, Chile started to install the provision of educational services using a market-driven model. The model started with the design of three types of schools: municipal, to be administered by the country's 341 municipal governments and totally financed by public funds through a per-pupil voucher system based on student attendance; subsidized private, to be financed through the same public voucher system but to be managed by the private sector, but where parents are usually charged an additional tuition; and private non-subsidized, run by the private sector and fully funded by parents. These three types of schools cater to different socio-economic groups (García-Huidobro, 2007), creating a tightly segregated school system, where municipal schools almost exclusively serve the low socioeconomic groups and private nonsubsidized schools almost exclusively serve high socioeconomic families, to the point that the OECD (2004) Report defined the Chilean school system as being consciously segregated. 
The market-driven model designed under the Pinochet regime has not only increased educational segregation, but it has also weakened the total enrollment of students in municipal schools. As of 2001, municipal schools represented 58\% of total enrollment, but in 2006 the percentage dropped to $46.6 \%$ of total enrollment, and in 2011 , to $40.7 \%$. On the other hand, subsidized private schools grew from $45 \%$ in 2006 to $50.7 \%$ in 2011. Research shows that the market-driven model boosted the growth of private providers and decreased municipal school enrollment (Cox, 2004; Taut, Cortes, Sebastian, \& Preiss, 2009).

\subsection{The civil-rights movement in education}

From a human rights perspective, the civil approach grants parents a civil right to participate in school affairs: within this view, education is seen as a formidable means of producing democracy (needless to say, when it doesn't work, of reproducing social differences). The rationale is that, since students spend most of their time in school, the school scenario is daily instantiation of civil rights. Dewey's (1927) conceptions of democratic communities, and his Proggresive Education movement - where schools are seen as real-life contexts of democracy learning through every-day democratic practices - would closely align with this approach. According to Anderson (2001), the civil-rights and human-rights movements closely align with concepts of participatory democracy, as opposed to formal representative democracy. Based on Dewey's (1927) notion of democratic communities, supporters of participatory democracies sustain that the future of democracy in global, pluralistic societies depends on the existence of local social spaces that allow actors to learn and develop the ability to dialog, discuss and confront ideas and positions, in order to develop authentic citizenry.

The United Nations' appeal for participatory school communities also views parental participation as another form of exercising civil rights (Bellei, Gubbins, \& López, 2002). Within the civil-rights view of education, parent participation in the school system is just another way of constructing citizenship. Within the framework of a democratic government that values collective organization and participation as a means of strengthening democracy and guaranteeing its continuity, mothers, fathers, and caregivers play a decisive role in school management. If parents are informed and get actively involved, give their opinion and take part in the decisions of the school, more participatory school communities will be constructed.

For several decades, researchers have promoted community participation in school-based decisions as a means to democratize schools and to build more involved societies. Within this approach, parent participation is viewed as a privileged means of empowering community actors and strengthening their competences to participate in issues concerning the due respect of cultural, religious, and other differences (Barber, 1984, 1992; Kahne, 1994).

Under this logic, parents are subjectivized as citizens, and parent participation is conceived not only as a mechanism that improves the management and quality of education, but more importantly, as a way of exercising citizenry rights, particularly the rights of children and youth to education. Parent participation is geared to achieve greater equality in this domain, and towards the strengthening of civil society. Organized forms of parent participation within the schools emerge as a privileged scenario for civil empowerment and for the 
construction of citizenry, an exemplary method of exercising rights and values, respect and tolerance to cultural differences, etc. All told, within this perspective, parent participation is viewed as a privileged space for the construction of participatory democracy (Anderson, 2001).

\subsection{The emancipatory stance in education}

A different approach towards education is the transformative or emancipatory stance. The origins of this approach can be traced back to Marxist analysis and to social-historical analyses, which influenced critical pedagogical views such as Bourdieu and Passeron's (1970) theory of social reproduction proposal in Europe; and Paulo Freire`s (1963) pedagogy of liberation in Latin America. The emancipatory approach views community actors as victims of oppression and schools as authoritative experts, and members of the dominant social class, who exert their power over students (and their parents) in order to preserve an ignorant labor force, ignorant of their transformational power (McLaren, 2000; McLaren \& Lankshear, 1994; Mayo, 2004; Morrow \& Torres, 2002).

The transformative approach views parents as agents of change. If parents participate not only in the school system, but also in the pedagogical processes of their children's learning, then they can bring to schools their culture and values, and transform the top-down curricula to make it more meaningful. Through their participation, they also become empowered. Parent participation is, therefore, a means of emancipation (Reca \& López, 2001; Lareau, 2003).

This approach is oriented towards the transformation of the entire school culture, so that the school may understand that parents are active, empowered agents of change. It promotes deep, profound forms of parent participation, especially in pedagogical issues that have historically been construed as within the field of the "teacher-expert". Ideally, parents participate in the design of the curricula, in the design and implementation of learning activities, not only as an assistant to the teacher, but also as an expert in specific processes of their children's learning processes. Parents' role is not only to care and provide for, but also to educate and teach. Hence, this conception seeks to make the relationships between teachers/school principals and parents more horizontal, by redefining the relations of knowledge-power traditionally established in the school systems by setting the stage for shared power among the different members of the school community (Reca \& López, 2001).

\section{Forms and modes of parent participation in Chile}

In Chile, as elsewhere in the world, parental participation takes one of two forms: individual or collectively organized participation. Individual participation is mainly viewed as pedagogical assistance outside school - "parents helping their children with their homework at home"- attending parent meetings, and complying with school rules and regulations. Parent participation in more direct modes of participation - for example, as assisting teachers in classwork - is infrequent (Bellei, Muñoz, Pérez, \& Raczynski, 2004). 
Organized forms of parent participation have been present since the second half of the twentieth century (Reca \& López, 2001), but were - as all other forms of collective community organization - bluntly downplayed during the military dictatorship. After the return of the democracy, the Ministry of Education collaborated several years with UNICEF in a project aimed at promoting organized forms of parent participation in Chile (Bellei, Gubbins, \& López, 2002), mainly Parent Associations and District and Regional-level Unions of Parent Associations. This project no longer exists.

The most traditional form of organized participation in Chile are the "Centros de Padres" (Parent and Legal Guardian Centers). Unlike other forms of parental participations, these are organizations formed exclusively by parents and care-givers. Research performed on organized parent participation in the school system in Chile within the framework of the UNICEF project mentioned above showed that the "Centros de Padres y Apoderados" (CPA) faced a lot of difficulties during the 1990s and the first years of the turn of the centry (Guzman, Hojman \& López, 2001; Flamey, Gubbins \& Morales, 1999; Martinic, 2002). Most difficulties can be traced back to a) their lack of representation (during the military dictatorship their representatives were designated by the school principals with no balloting taking place whatsoever; in those days, even though elections did take place, many parents still believed that CPA representatives were colluded with the School Principal, in the sense that they or their children received certain benefits in return for going along with the Principal's actions and rhetoric (Martinic, 2002); or b) their focus on fund-raising initiatives aimed at improving the School's deteriorated infrastructure, which distracted their attention from the schools' "central issues".

A wider, commune-based form of organization, the 'Uniones Comunales de Padres y Apoderados' (Communal Union of Parent and Legal Guardian Centers), a relatively new form of participation -initiated in the early 1990s- that geographically groups the former schoolbased Parent and Legal Guardian Centers into district organizations, showed at the beginning of this century the potential of promoting the civil-rights and transformative approach through self-organized parent training (Reca \& López, 2002; Guzmán, Hojman, \& López, 2001). In 2001, Guzmán et al. (2001) were able to obtain information from 35 of these Commune Unions of Parents (representing $10 \%$ of all the communes of Chile). Through a qualitative study with focus groups and interviews, they described how those organizations were almost always initially formed by the initiative of the Municipal Directorate for Education (DAEM), so they, were also hindered by a perceived lack of representation by parents. However, for the members of these Unions, being part of a collective form of participation translated into hopes of positioning parents as relevant actors in education: they wanted to

"Change a little the vision that has always been present. We have always thought that we just have to unite to fix things or to ask for help. The idea [behind forming a Communal Union of Parents] that I have is that we can give our time and our ideas, and also receive the orientation from professionals and be able to work together" (Guzmán, Hojmann E López, 2001, translation is our).

Notice how in this quote parents still assume educators are experts, and they themselves need education. In fact, much of the work done by UNICEF at the time was to provide 
training to representatives of Unions and Communal Unions in topics such as laws and regulations, communication skills, etc. (see Flamey et al, 2002).

The relationship between parents and schools was consciously described as vertical in some of the Communal Union representative's discourse: "There is an authoritarian relationship of school principals with sustainers, teachers, parents and sometimes even with students, but in isolation we don't work like a system....we don't interact as a community, we are kept apart in static compartments" (Guzmán et al., 2001).

Current research is need as to the whereabouts of these Unions and Communal Unions. Our informal experience with former leaders reveal that the high hopes of social transformation, of "changing the vision", are still present but have been very hard to achieve due to difficulties in relating to school principals and school management teams, as well as to the media; but that the human-rights facet is very much a focal point in their work. A President of a Communal Union of Parents in northern Chile described his work in supporting parents whose children were "invited to attend another school" to the first two authors at a Regional Conference on Education organized by another Communal Union of Parents - a frequent form of subvert school expulsion-, or parents whose children were not being accepted in a public municipal school by taking them to the District Department of Education (in Chile, El Departamento Provincial de Educación) to talk to government officials and, if needed, to start a lawsuit.

At the beginning of this century, the Ministry of Education promoted a new form of parental organization: School Councils, whose level of functioning is included within the SNED national school achievement assessment system. Internationally, school councils have been conceived as a collegiate form of school participation, where representatives of different actors would get together to discuss and make decisions about issues concerning the school. In countries such as England, school councils not only receive information and are asked for their opinion, but they also vote and decide on administrative and pedagogical issues, such as the continuity of educators. Therefore, they have, at least in writing, the chance to enforce the transformation of the school.

In Chile, the Bill that created School Councils was passed in 2004, together with the extension of the school day (Jornada Escolar Completa). Their purpose, officially declared, was to provide a means of collegiate democratic participation across actors. The law mandates that every public (municipal and subsidized) school must have a School Council, "which will be of an informative, consultative and propositional nature, except if the school provider decides to grant it a resolutional (o.e. decision-making) nature" (Law 19.979, Article 8). The School Council is integrated by the school provider or his/her representative; a teacher elected by his/her peers; the president of the CPA; and the president of the Student Union only when the school has secondary education. Article 8 mandates that "the School Council shall be informed, at least, of the following matters: a) student learning achievement records; b) reports of visits by the Ministry of Education inspectors concerning the application of legal mandates; c) in municipal schools, the outcomes of selection processes of teachers, teaching assistants, staff, and school officials, d) yearly budget; d) quarterly income 
and expense statements. The same article also mandates that, "the School Council will be consulted, at least, on: The Institution's Educational Project, normal and extracurricular program for the current exercise, goals and improvement projects, , a written account by the School Principal of the school's annual educational management, before presenting it to the community, plus a review of the school's rules and regulations. However, Article 8 of this Law also specifies that the School Principal may revoke the resolving nature of the School Council at the beginning of each school year:

"Article 8..- The School Council will have an informative, consultative, and propositional nature, except if the school provider decides to grant it a resolution nature. In any case, the resolving nature of the School Council can be revoked by the school provider at the beginning of each year".

This was the outcome of fervent lobbying at the policy-making level, mainly from rightwing, but also center-wing politicians actively involved as shareholders in privatesubsidized schools, who might have been pressed by these schools. For many people who drafted the Bill, this last phrase declared the "natural death" of the School Councils, or at least, stifled its transformational power.

Eight years after their implementation, only one study has assessed their progress and outcomes (De la Fuente \& Raczynski, 2010). This study found that most schools had formally formed a School Council, but had not taken ownership of it as an instrument of democratic representation, so that most schools councils were left to "accomplish a merely formal role, with no influence in the lives of the institutions" (p. 66). Although this was the image portrayed by most schools, some school councils were actually having a slight impact, and very few cases were their impact was being significant. The authors conclude that the impact of the school councils was closely influenced by the conditions and contexts of the schools:

"The features of the schools where the school council "lands" defines the shape these spaces take. In this way, it is rare to find a "good school council" in an elementary or high school that does not have adequate conditions, such as educational leadership willing to allow the participation of all school stakeholders, or an environment that promotes understanding and trust across all stakeholders of the school community" (De la Fuente E Raczynski, 2010, p. 66).

These paragraphs outline different forms and modes of participation that can be linked to the diversity of underlying logics or conceptions of education described in the previous section (see Figure 1). While the logic of neoliberalism clearly mandates parents to participate as consumers, it also suggests certain forms of parental participation, mainly at an individual level, and depicts a certain mode of participation as dominant: parent school choice. Likewise, the logic of civil rights based on the human rights approach, assumes parents are predominantly laymen, and foster the development of collective and organized forms of parental participation as most appropriate. In Chile, the dominant collective and organized form of parent participation has endured time, through Parent Organizations, and in the last decade, through Unions of Parent Organizations. Finally, the emancipatory or transformational logic of education calls for parents to act as agents of social and educational 
change, through different forms of participation at the individual level but mainly also the organized and collective levels. Within this logic, parents are invited to transform the school and students' learning processes through active involvement, be it individually through their pedagogical involvement, at home and in the classroom, redefining the relations of knowledge-power from within and establishing relationships based on shared power between members of the school community; or in an organized mode such as school councils; and collectively, through social acts of transformation such as public manifestations.

\begin{tabular}{|l|l|l|l|}
\hline $\begin{array}{l}\text { Logic of } \\
\text { Education }\end{array}$ & $\begin{array}{l}\text { Subjectification of } \\
\text { Parents }\end{array}$ & $\begin{array}{l}\text { Forms of Parent } \\
\text { Participation }\end{array}$ & $\begin{array}{l}\text { Dominant Modes of Parent } \\
\text { Participation in Chile }\end{array}$ \\
\hline Neo-liberal & $\begin{array}{l}\text { Parents as } \\
\text { consumers }\end{array}$ & Individual & School choice \\
\hline Civil-rights & Parents as civilians & $\begin{array}{l}\text { Collective and } \\
\text { organized }\end{array}$ & Parental Associations \\
\hline Emancipatory & $\begin{array}{l}\text { Parents as agents of } \\
\text { change }\end{array}$ & $\begin{array}{l}\text { Individual, collective, } \\
\text { and organized }\end{array}$ & $\begin{array}{l}\text { Pedagogical involvement } \\
\text { School councils } \\
\text { Public demonstrations }\end{array}$ \\
\hline
\end{tabular}

Figure 1. Forms and modes of parent participation in Chile, their relation to different types of parent subjectification, and to different underlying logics of education.

In the remainder of this chapter, we focus on parent school choice as of the current form of parent participation in Chile. We pose that, although the other modes of parent participation are still present in our country (Parent Associations; School Councils; individual pedagogical involvement, and during the year 2011, public demonstrations), parental school choice is being portrayed as THE most important form of parent participation. Underlying this mode of participation is an individual (not a collective, not an organized body) and narrows form of participation. Underlying both mode and form is, of course, a neoliberal logic approach to education.

We draw from results reported in the literature as well as from original data obtained through a discourse analysis performed by the third author (Sisto) on recent information given to parents by the central government. The discourse analysis was performed using as corpus the government letter accompanying a document called "The traffic light Map", produced by the Ministry of Education in order to provide "more information" to parents. Our purpose was to analyze the types of actions promoted by this instrument aimed at parents and legal guardians, in order to understand how parents and legal guardians are understood by government policies. We took the "Traffic Light Map" as an instrument meant to mold the actions of these actors coherently with the logic of neoliberalism.

In addition, we draw from two unpublished studies in two regions of Chile conducted between the years 2009 and 2010. Both studies were carried out by the second author (Madrid) while working at Programa CRECE, a University-based technical-assistance program for public schools based at Pontificia Universidad Católica de Valparaíso. Study 1 was performed in a rural community of Region VI in Chile and its purpose was to describe 
the perception of the educational community about the public education provided by the local Municipality (CRECE, 2009). This study had a quantitative phase and a qualitative phase. In the first phase, a questionnaire was designed and applied to capture the perception of the full student enrollment of all 25 municipal schools in the community. Out of a universe 4.200 , within a $95 \%$ confidence level and a $5 \%$ error, the sample size was set at 453 cases. A total of 1,957 questionnaires were completed. In the second phase, a series of focus group sessions were conducted with participants drawn from the parent pool who were asked to complement and drill on the information obtained by means of the questionnaire. Five focus groups were conducted with parents who qualified on two dimensions: they had to live in different locations within the community and have a different number of years of experience with the school. Candidate participants were drawn using the data contained in the questionnaires, picking 34 of them at random, to contact by telephone. Focus groups had 5-7 participants each. These were recorded, transcribed and later analyzed through content analysis.

Study 2 aimed at understanding the process by which parents and tutors chose a school. The methodology chosen was qualitative and had an exploratory character (CRECE, 2010). The sample was made out of four female parents who lived within the same neighborhood and had the same socio-economic status. The selection criteria was dichotomous: two of the participants were chosen from the pool of parents who had chosen to have their children leave the municipal school and attend a private-subsidized school; the other two had chosen that their children would remain studying in the municipal educational system. Two interviews were conducted in depth with each participant. They were recorded, transcribed and later analyzed using content analysis.

\section{Parents as consumers of education}

The logic of neoliberalism assigns parents the role of consumers of education, placing the emphasis on their right to choose schools. As consumers of pre-existing educational products-services available in the marketplace, parents have the right and freedom to choose, according to quality and preference, based on educational outcomes and valuedriven of preferences. Election is a central aspect of this logic (Reca \& López, 2001).

In this section we look at this mode of participation in Chile, from two perspectives. First, the role of central governments during the last three decades and how this role has changed with the change of governments; and second, the ways in which parents end up choosing schools, and the reasons underlying their choice.

\subsection{The government's call for school choice}

As pointed out earlier, in the eighties, out of the political regime under a dictatorship, Chile underwent a radical restructure of the financial and management components of its educational system by introducing a demand-driven subsidy. This in turn meant student and their parents became economic actors, with the latter being in charge of deciding and selecting the "best" educational offering, within the logic of market forces. One of the most 
relevant assumptions of this perspective has been the conviction that freedom to choose a school not only improves the degree of satisfaction of parents and students but also stimulates a systemic change, thus directly improves the quality of education. (Neal 2002; Hoxby, 2001, 2002; Byrk \& Schneider, 2002; Plank \& Sykes, 2003). This improvement of schools is the result of competitive pressure stimulated by parents and tutors. Consequently, under this educational model, parents and particularly their ability to choose is paramount to the proper performance of the educational "market".

During the 1990s and the first decade of the XXI century, the Coalition did not engage in active efforts to stimulate parent school choice. Information on school academic results was available in schools, and once Internet penetration grew in the country, the central government set up a web page containing results of the national quality of education assessment system (Sistema Nacional de la Evaluación de la Calidad de la Educación, SIMCE; www.simce.cl). Progress on this web page includes the display of results as a nested scheme, where schools are compared to the standardized mean of schools of the same dependency. Since dependency is often used in Chile as a proxy of socioeconomic status (SES) due to the high segregation and stratification nature of the Chilean educational system, this nature means parents are invited to interpret their school's academic records by comparing them to schools of similar SES. However, given that the rate at which Internet facilities are actually used by medium-low and low SES families is been low, the usefulness of this data to inform parents when choosing schools was rare; the web page has probably been used more by researchers than by parents.

One of the first educational actions undertaken by the first right-wing government that won a democratic election in 2010 was to provide "more information" to parents, so that they would in a better position to exercise their right to choose schools. During the first months after winning the election, the newly appointed Ministry of Education implemented a rating system that ranked schools based exclusively on the latest SIMCE test scores. This information tried to "nurture" stakeholders' decision-making pertaining to school enrollment. The "Traffic Light" (semáforo), as promoted by the Minister of Education, was a system where schools were ranked by their last SIMCE scores against nearby schools of the same commune. Parents received a "traffic-light map" in which schools were marked red if their score was below the national average; yellow if it was similar, and green if it was above the national average (see Figure 2). The rationale was that, if parents were better informed about the SIMCE results of their schools, they could make better decisions as to where to enroll their children. Unlike the SIMCE website available during the last decade, the "Traffic Light Map" does not reveal additional information, omitting data such as the SES background of the students.

Figure 2 shows the "Traffic Light Map" given to parents in one city of the Region of Valparaíso. This is a sea-side city, with the Pacific Ocean to the West, and medium-sized hills to the East. In this city, the poorer neighborhoods are located east, that is, in the hills. The "Traffic Light Map" shows most red dots (below national average) are located in the hills, and that most green dots (above national average) are located near the bay area. So, this is actually a "map of poverty and segregation". The concentration of green and red traffic lights follows a pattern of income level differences. The majority of the red dots correspond to public municipal schools, which, as we have described above, serve mainly children from 
lower SES, and the majority of green dots correspond to private schools serving children from higher SES backgrounds. Curiously, public information still exists in the SIMCE website, which takes contexts into account. Moreover, a pamphlet explaining the school's scores was designed and delivered to parents that year, comparing schools with similar contextual features, but a decision was made to give more publicity to the SIMCE map in the media, as a means to empower parents when choosing a school for their children.

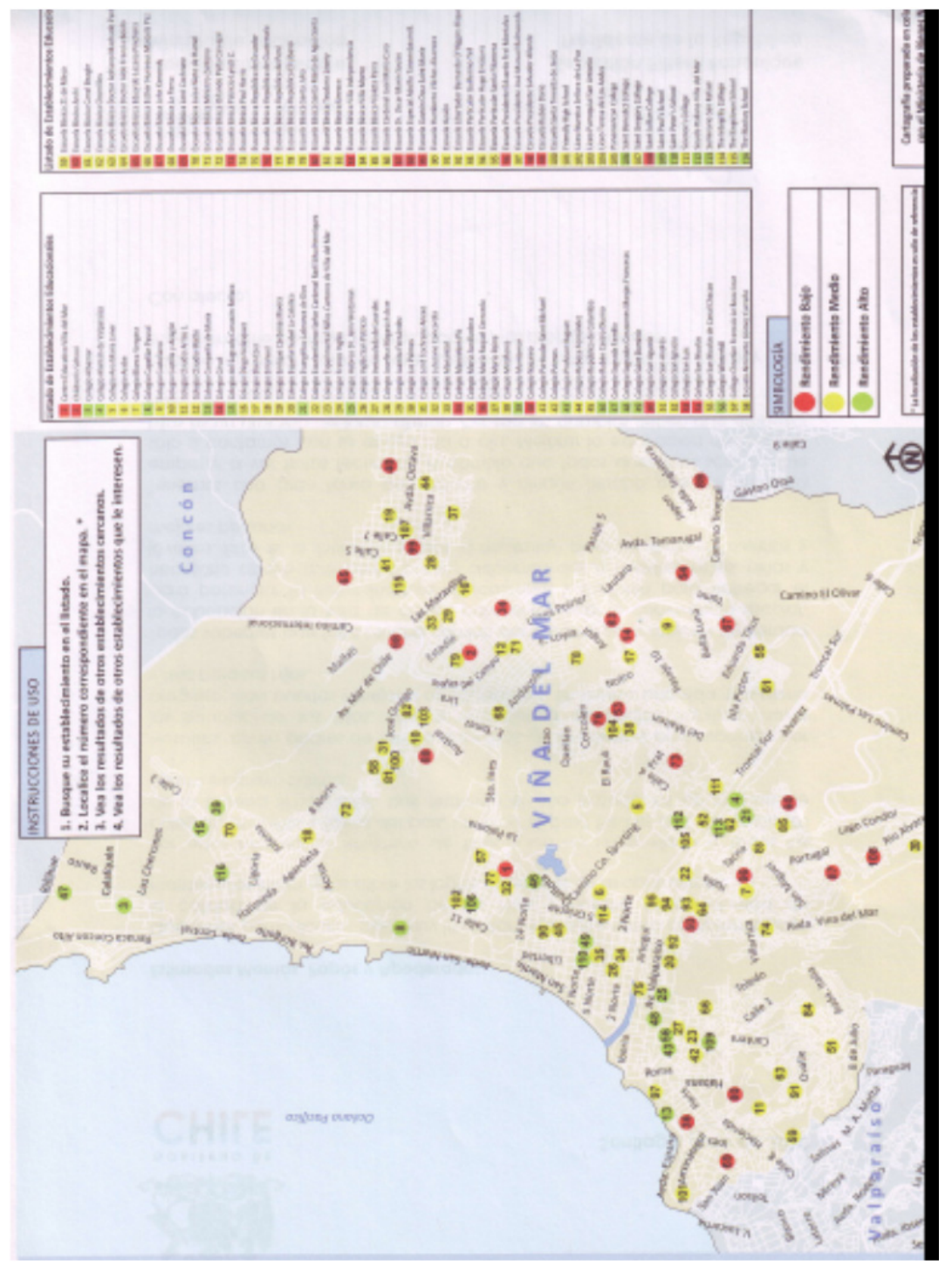

Figure 2. "Traffic Light Map" sent to parents by the Chilean Ministry of Education during 2010 in one commune in the Region of Valparaíso 
The "Traffic Light Map" was given to all parents along with a letter signed by the recently elected President Sebastián Piñera, and by the former Minister of Education, Joaquín Lavín (see Figure 3). Both documents were given to all parents whose children were enrolled in public municipal schools. Its explicit purpose was to inform parents about the learning outcomes of different schools in the commune through a commune territorial map, with the green, yellow, and red dots indicating not only the school's location, but also their results on the last SIMCE test, as compared to the national norm (with the standardized mean set at 250 points).

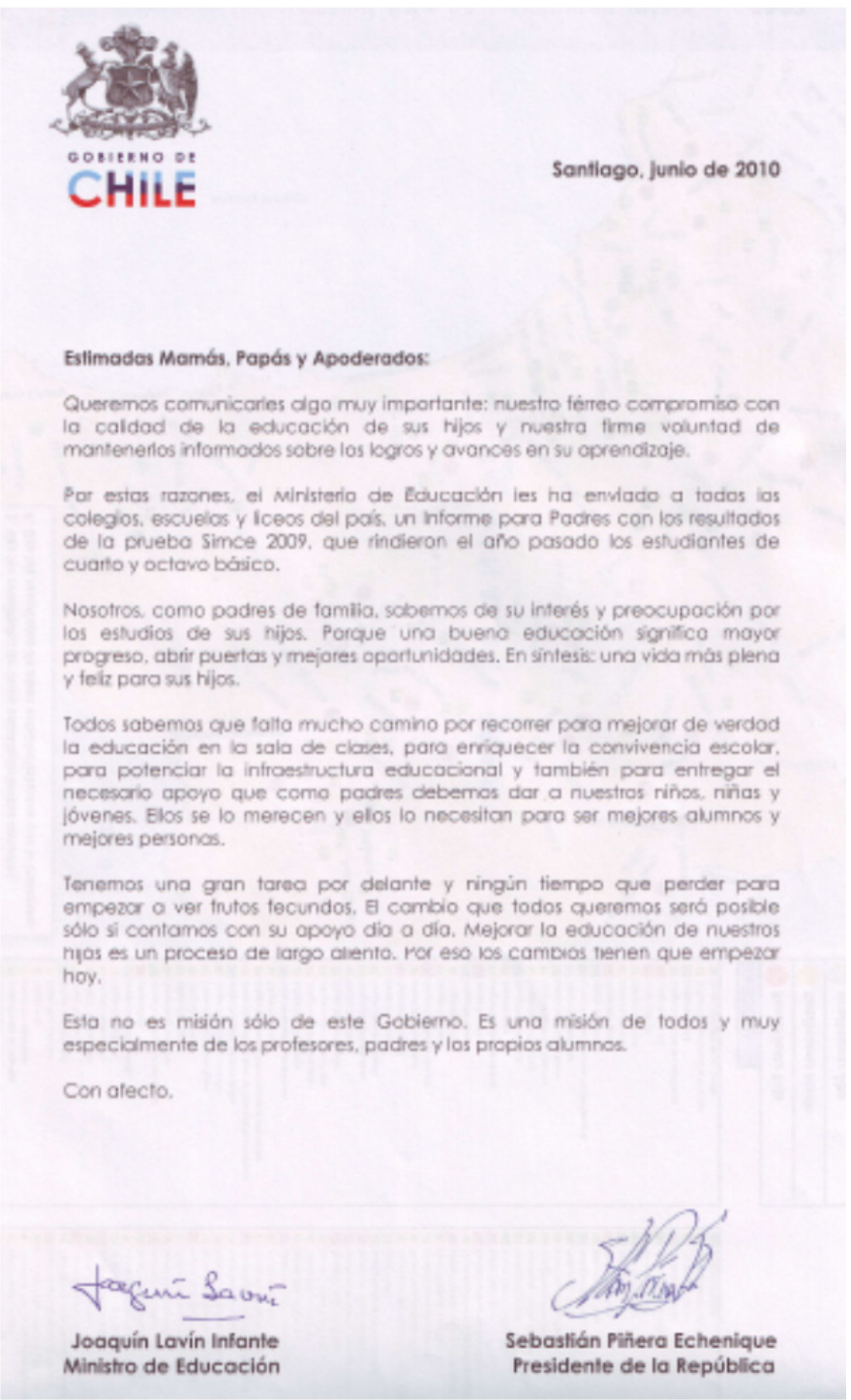

Figure 3. Letter sent to parents along with the "Traffic Light Map" by the Ministry of Education in 2010. 
Following the criteria of discourse analysis, we used the criterion of representativity developed by Ibáñez and Iñiguez (1996), according to which texts are representative if they are habitual products in the context to be analyzed, and if they manifest the relation under study (Iñiguez \& Antaki, 1994). Public discourses from Ministry authorities, as well as leaflets and manuals for dissemination, are rich sources for analyzing how the justifying rhetoric in which transformations are installed in the public agenda operate by seeking social legitimacy and appealing to the identities of the social actors involved.

The text was analyzed following the principles of Discourse Analysis as developed by the Discourse and Rhetoric group of Loughborough (Potter \& Wetherell, 1987; Billig, 1996; Wetherell et al., 2001). This type of analysis confronts texts as forms of social action. As Ibáñez and Iñiguez (1996) propose, the task of this type of analysis is to "bring to light the power of language as a constitutive and regulatory practice" (p. 75). This is why the orientation is pragmatic and rhetoric. This analysis allows understanding how, through different texts, rhetorical strategies are deployed which construct certain versions of reality. In this case, certain versions of identities become convincing, thereby undermining alternative versions. What we present is not detailed in the sense of the rhetoric and linguistic perspective of discourse analysis. Its purpose is to use this analysis as an illustration of the type of relationship that is being tried to be built between State and parents.

The text begins as follows:

Dear Mothers, Fathers, and Legal Guardians:

We want to communicate to you something very important: our tight commitment with the quality of your children's education, and our commitment to keep you informed about the achievements and advances in their learning outcomes.

For this reason, the Ministry of Education has sent a Report for Parents with the results of the SIMCE 2009 test taken by forth and eight graders to all elementary and high schools of the country.

As we can appreciate in this fragment, at the beginning of the text the speaker takes the stand of someone that is "tightly committed" to quality in the education of children of "dear mothers, parents, and legal guardians", explaining in the context of this explicit "commitment", the "commitment to keep them informed of the achievements and advances in their learning outcomes". The document is thus delivered with this framework of reference, namely the "results of the SIMCE 2009 test", omitting any mention to its comparative nature.

This first paragraph shows a remarkable rhetoric operation: the document is constructed as a report of outcomes, not as a comparative report, and emerges as an expression of the commitment declared by the authorities to the quality of their children's education. The responsibility of the authority is constructed as informational. This is articulated together with the responsibilities allocated to parents as is indicated in the next paragraph: 
As parents of families, are aware of your interest and of your concern about the studies of your children. Because a good education leads to a higher rate of progress, opens up doors and better opportunities. In synthesis, a fuller and happier life for your children.

In this text, one can see how the speakers identify with the parents, subjects addressee of this missive. The authorities describe themselves as being parents. This displacement serves the purpose of accounting for the duties and responsibilities of the speakers, appealing directly to the addressees. A good parent must take interest and worry about the education of their children. The reason the text offers for this interest, has to do with the fact that a "good education" is constructed as a means through which their sons and daughters may "progress". The text is constructing education as being responsible for social mobilization, and this in turn means that the "doors will open" and that better opportunities will arrive, "in synthesis, a fuller and happier life". Therefore, in this paragraph responsibilities are construed, with a strong moralizing character, since if parents do not accomplish their responsibility, what is at stake is their children's happiness.

It is important to pause at this point. The document, a "traffic light of education" that is presented through this letter, is depicted simply as a report of "their children's learning outcomes", not as a document that compares schools. In this document, the best and worst results of the commune are presumably presented. The parents and legal guardians to whom the document gets delivered, are indicated that the information is being delivered as part of the State's commitment, and that they, as parents and legal guardians, must act accordingly, since if they don't, they would be failing their responsibility, hindering their chance to achieve happiness and a full life.

Even though the letter does not explicitly suggest what parents should actually do, it implies that the responsibility of choosing a school is theirs. A school indicated with a red dot is taken as a poor quality school, and along with that, of being unable of providing the means to have their children make progress, be happy, and enjoy a full life. The State has thus accomplished its responsibility of informing, it is now the turn of parents and legal guardings.

The text ends with the following statement:

We all know that there is a long way to go to really improve the education in the classrooms, to enrich school coexistence, to foster educational infrastructure, and also to deliver the necessary support that we as parents must give to our children and youth. They deserve it, and they need it in order to become better students and better persons.

We have a big task ahead of us, and no time to waste to start seeing fertile fruits. The change that we all want will be possible only if we count on your daily support. Improving the education of our children is a long-breath process. That is why the changes need to start today.

This is not only this Administration's mission. It is an everyone's mission, and very specially, one for teachers, parents, and the students themselves.

With affection

Joaquín Lavín Infante

Minister of Education
Sebastián Piñera Echenique

President of the Republic 
This closure reinforces the idea that the improvement of education is the responsibility of all, alluding explicitly to parents and legal guardians, reinforcing the moral load of this mandate: "they deserve it and they need it to be better students and better persons". Through the use of the first person plural (us), the subject addressee of this letter is appealed to as being accountable: "We have a great task ahead of us and no time to waste". And, as the text goes on, "the changes need to start today".

In this manner, the subject - mothers, fathers, and legal guardians- are appealed as accountable for the education of their children. Since this letter labels the document as the "Traffic Light of Education", the responsibility is clear: school choice. Placing your child in a school marked as red is condemning his/her future. What you should do is to place your child in a green-dotted school....this is how you can give them the opportunity to live a plentiful and happy life...this is the duty of parents. The recipient of this letter cannot do anything else, since the moralizing force appeals directly to the subject, forcing him/her to act accordingly.

\subsection{Parental responses to school choice}

Beyond of the agreement of policies about school choice in Chile, how have parents reacted over time, and how are they currently responding to the mandate of school choice as the dominant mode of parent participation?

In families of middle and higher income, social status seems to be a key factor. Elacqua, Schneider, \& Buckley (2006) studied the school selection behavior of parents in a large urban area and found that the social class composition of the student body was a key factor. Their findings stressed the importance that affluent parents place in schools as a space for fostering the building of social capital, since students interact with other equally or more affluent families, thereby exacerbating stratification and segregation. As Montecinos, Sisto, and Ahumada (2010) pose, since this factor is more relevant than the school's overall performance on academic records, the idea that choice will increase quality seems unsupported in the case of Chile's highly socially stratified society.

Moreover, in order to compete, many private subsidized schools have implemented selection processes to exclude those who might have a negative impact on tests scores or that would "drive quality down". Given this practice, it is the school that chooses the family and not the other way around! Schools are choosing parents through stringent selection processes and voiding enrollment if the student does not "adapt to the school". The "chosen few" are those with high economic, cultural, and social capital (Bellei, Muñoz, Pérez, \& Raczynski, 2004).

Municipal schools, on the other hand, do not select their students. They cater to all students, including those rejected by private entrepreneurs, students from low-income families. In Chile, therefore, the market has introduced competition among families (consumers) and not among schools (providers) (Montecinos, Sisto, \& Ahumada, 2010). 
Thus despite the benefits of freedom to choose proclaimed by Friedmans'(1955) market theory $^{1}$, research in Chile has shown that the main consequences of three decades of implementation of this model in education have been the segmentation of the educational system and a modest track record of achievements in terms of learning outcomes (Elacqua \& Fabrega, 2004; Bellei, 2007). Critics of this model have emphasized two important issues. First, that information provided by the outcomes of standardized tests do not qualify as a trustworthy and faithful source for parents to choose a school mainly because a) standardized, norm-referenced test outcomes are a better reflection of the socio-economic composition of students than of the educational quality across schools, b) the high volatility of those results from year to year do not allow the delivery of stable nor trustworthy information to differentiate schools (Urquiola, Mizala \& Romaguera, 2007). Second, that the selection process does not operate using the expected academic-driven rationale. Several studies (Mizala \& Romaguera, 2000; Elacqua 2004; Urquiola, Mizala \& Romaguera, 2007) provide evidence that in general legal guardians and parents with broad educational backgrounds do not prefer quality information as understood from the SIMCE (Sistema Nacional de Evaluación de la Calidad de Educación, our national stakes test for elementary and high school) or PSU (Prueba de Selección Universitaria, our national university entrance test) test outcomes over other elements. Nor are legal guardians and parents of low SES choosing schools based on these academic-driven reasons.

A quantitative study conducted by Elacqua and Fábrega (2004) found that parents in municipal schools ended up choosing the school for their children mainly based on "practical reasons" among which the argument "that our child would go to a nearby school, that the school was the only available option, cost, security, proximity to work, schedule, our family works in the school standout" (Elacqua \& Fábrega, 2004, p.32). On the other hand, according to these authors, "Parents from the subsidized private sector are more likely to choose based on values and $\operatorname{curricula}^{2}(\ldots)$ and are more keen about indicators of schools of their choice as compared to parents from the municipal sector" (Elacqua \& Fábrega, 2004, p.24). This study came to the conclusion that the following statement applies to parents from either sector:

“(...) use few sources of information, have weak educational networks, take few schools under consideration, end up choosing for practical reasons and deal with very few pieces of precise information about the schools they choose. Besides, the quality of the sources and networks and the precision of knowledge about the schools are a function of the socio-economic level and do not depend as much on whether the school being chosen is a subsidized private school or a municipal one" (Elacqua \& Fábrega, 2004, p. 38).

These criteria applied to school choice are confirmed by research that show that in many communes, and consistently over time, public-subsidized schools do not show better results

\footnotetext{
${ }^{1}$ It is important to note that Milton Friedman (1955) was the first to propose the voucher system as a means to mobilize market forces to improve education.

${ }^{2}$ The value category refers to religious affiliation, discipline, tradition and prestige, which are values taught at school. The category curriculum refers to language used throughout the day, to the material being taught, personalized education, infrastructure, and to whether or not it is co-ed (Elacqua, 2004).
} 
on the SIMCE test than public-municipal schools (Bellei, 2007), but that parents still prefer them over public schools, to the point that the amount of public/municipal schools have steadily decreased in the last few years.

Córdova (2007) analyzed school choice processes in poor neighborhoods in Santiago. Their findings point in the direction that the main reasons that mothers choose schools are: proximity of school and home, familiarity with the school (personal experience or that of relatives who are alumni of the school), the notion that education provided by municipalities is free, and the perception that it happens to be a good school. To mothers that were interviewed, a "good school" manages to have students learn and grow-up properly. The main indicator that mothers use to assess schools in this count is learning how to read and write and being able to use the four basic arithmetic operations. They also see if their children are developing several skills, such as being able to address public audiences. In line with this argument, a good school is one where teachers care as much about learning outcomes of children as about their emotional or social development. It becomes particularly important for teachers to provide additional help to students with learning disabilities. The same applies to the way they value that the school is in order and disciplined, demanding the same behavior from officials, teachers and students.

These findings have been confirmed the second author in urban and rural contexts in Chile (CRECE, 2009, 2010). A mixed-methods research on Mid-to--low SES parents choice of school, in a urban commune in Chile's Region VI (Study 1) showed that parents choose public/municipal schools based on geographical proximity to their homes (40\%), tradition and previous experience with the school, i.e. parents are alumni of that school (19\%) and because the public/municipal school is free $(10 \%)$. On the other hand, parents who choose public-subsidized schools do so based on the perception of their academic performance $(14 \%)$, geographical proximity $(11 \%)$, infrastructure $(8 \%)$ and perceived discipline $(8 \%)$ (CRECE, 2009).

The findings were confirmed by research in rural sector as well. Based on a survey and group interviews to parents, a study in a rural commune in Chile's Region VI shows that parents choose public/municipals schools also based on the same factors mentioned above (CRECE, 2009). Geographical proximity is a central reason for these parents mainly due to the costs of commuting, should they decide to send their children to a distant school. This is evidenced in the following excerpt:

A2: "let's see I'm going to get to the same previous topic, meaning I was counting on sending them to ..., because my nephews study there, and my sister used to tell me it is a super good school, but because of the commuting issue I placed them here".

(Focus 2, Legal guardian, Rural School)

In the opinion of these parents, choosing a public/municipal school was influenced by trust in the school and by having a close relationship with its teachers. Trust in the school and appreciation of the work by teachers is the product of a long-term relationship between parents and schools. Parents and relatives are generally former students of these schools. 
Therefore, their acquaintance with the teachers, principals explains their judgment about the school, which plays a very important role when choosing a school.

A5: “(...) you (already:::) knew the teachers, you become almost a friend to the teachers (.) then you feel closer to the teachers than at other schools, they know you, so you trust.

A6: "it's just that they already know you, so you trust them. That's why I put them here"

(Focus 3, Legal guardians, Rural School)

A1: "Me too, my whole family studied there, they graduated from that school (.) That's why I still have my daughter there, and because I like the way it is (..)".

(Focus 2, Legal guardian, Rural School).

Thus, the value of familiarity with the school appears to be a selection criterion placed above learning outcomes, and above measurable school performance. It is unclear if SIMCE test scores played any role as a criterion used by parents, since they did not explicitly mention this criterion in the interviews, and when asked, their answers were unclear. Parents seemed to prioritize historical and relational components when choosing schools. At the same time, those elements emphasize their beliefs about what is the purpose of education, which is mainly formation on values:

A3: "I think more than anything not as much in the outcome, because SIMCE is taken by many children and maybe not everyone in the classroom performs the same way, but as I was saying, in their learning (.) in that they learn values, in that they will do well in whatever they choose to become (...) the fact that they further their education(.)" (Focus 4, Legal guardian, Urban School).

Study 2 was developed in a central region of Chile (CRECE 2010). This qualitative and exploratory research focused on the experiences of four urban low SES parents about school choices, in an urban commune. The sample included four legal guardians, with two of them having just decided in favor of a private subsidized school and the other two having recently chosen to keep sending their children to a municipal/public school. Based on this difference it was possible to explore the selection a criterion was used in both cases, and to drill on the process of school choice itself. This research confirms the aforementioned practical criteria (proximity, cost) and those related to shared past experience with the school and the trust that was built on teachers and other school people as key aspects behind the choice, particularly in cases when mothers chose to stay within the municipal educational system.

"PAR: Sure, because when you are already here ... whatever, my children were here the full eight years the eldest and after eight years it looks like we became fond of it. Ignacio was let's see ... eight years and Diana ... when Ignacio was in Eigth Grade Diana was in First Grade ... in that many years (you) get involved with the school." (Legal guardian 1, Municipal School).

"A teacher who becomes familiar, one who you can approach with more confidence, it is your children that you are placing, then you get attached more or at least me, I get attached to that truth in fact here I would tell him anything or call him by phone even he would call me by phone 
... ma'm you know the girls fell down, so I am taking them to my home (...) you won't see that in another school, least in a private school I believe you won't see that" (Legal guardian 2, Municipal School).

Additional elements which had not been identified previously in the literature surveyed emerged. In the case of mothers who chose private subsidized education, a number of practices and meanings emerged that were associated with the notion of "school shopping" and thus with the notion of the legal guardian as a consumer of educational services. In these female legal guardians the idea of looking for schools other than municipal ones emerged. The main reasons put forward by participants were based on the possibility of getting access to a better disciplined environment and the perception that a better quality education does exist in those schools (measured in terms of things like the number of notebooks used, more notebooks stand for better education). Besides, it is interesting to note that the motivation for switching to a private subsidized school was based on the poor perception of municipal education. The most critical aspects along this line were the poor discipline record of municipal schools and the idea that, since municipal schools do not have student screening criteria for selection purposes (as opposed to private subsidized schools), the pace of education in municipal schools is slower, since they must adjust to the learning level of all children involved. In this sense, the two female legal guardians whose private subsidized education believed that municipal schools should focus on boys and girls with major learning shortcomings.

"I don't know if it is a norm, or I don't know why it is so differentiated, but you can tell that municipal education is slower. I don't know if it is better or worse, but I find that for example if a child falls behind, obviously the municipal one is good for her because it assumes the pace of the child so she may get it at a slow pace, but if the child is an over-achiever, it is her that falls behind so darn, I miss going faster or something like that" (Legal guardian 2, Private Subsidized School).

"Ricardo used to read all letters and tells me, Mrs. María Inés I was surprised by Ricardo's reading skills, yes I told her, Ricardo already reads and tells me darn, hopefully we will not have any problems, why? I told her, because he can get bored, he may be bored in class he is the first to finish in class, he knows how to read, he knows about this other stuff ... kids go slower, then I have to keep their pace because they are a majority, then Ricardo may get bored" (Legal guardian 2, Private Subsidized School).

Even though the data presented above are part of an exploratory research agenda, they are relevant to emphasize how, in cases where parents choose private subsidized education, clear indications emerge about their addition to the selection logic, since they start by "window shopping" for schools and to look within this type of schools those that assign priority to their own values (discipline, "plus" learning outcomes). The weaknesses of municipal schools, partly due to their structural features (they do not select students), as perceived by participants, have been paramount when choosing private subsidized schools. This way, the female legal guardians in this study reflect how parents and legal guardians from the private subsidized sector seem to be adding to the notion of education consumers. Given current 
growth rates of the private subsidized sector in Chile and the concomitant decrease of public municipal enrollment, these findings are relevant. Also worth mentioning is how criteria that justify and potentially stimulate student segregation show-up in female legal guardians' perceptions. In their narrative, municipal schools become schools geared to cater to certain groups of students, "the slow ones" versus schools that cater to "the more advanced. That is to say, the "undesired" as opposed to the "desired" students. This is not a minor issue, when accounting for the effects the private subsidized sector may have in terms of student segregation in Chile. These findings pair up with Elacqua's (2011) research which shows that the perception of interviewees is that municipal schools tend to get students with deeper learning shortcomings, since these schools cannot lawfully have student screening processes, something that does exist in the private subsidized sector. "Public schools are more likely to serve disadvantaged (low socioeconomic status and indigenous) student populations than private voucher schools. (...) disadvantaged students are less segregated in the public sector than in the private voucher sector" (Elacqua, 2011, p. 451).

As observed, there are reasserted elements in different studies which tell us that the choice does not seem to be driven by academic quality criteria defined by a central authority - be it a Ministry, Municipality or School - but by other criteria, sometimes of a practical nature and sometimes also based on the perception of prestige and social status, which say more about the cultural assets of the families of the students attending the school than about learning outcomes of students or of the educational results of the school. In the case of low income legal guardians (Córdova, 2007) and in urban and rural contexts (CRECE, 2009, 2010) there is a clear allusion to symbolic and cultural aspects associated to the notion of a good school, as well as to the affect and formative aspects that parents expect to receive at school. From the standpoint of parents, these aspects configure a process of school choice that we can label as not rational in relation to the current educational model. The expectations of educational policies that assume that the information about academic performance (SIMCE) is being used rationally to make decisions, seems to be flawed according to research findings. The above mentioned studies mirror that the school choice process reflects an alternative logic that does not match the logic expected and promoted by the central authority.

Based on the evidence presented, it is difficult to conclude there is a dominant tendency about how parents construct their options when choosing a school. On the one hand, parents and legal guardians from the municipal/public sector do not seem to portray the idea that parents participate in education as consumers, because they assert other elements in the school selection process, among which values and school orientation stand out, as well as shared paths between parents and educators, the levels of trust that get built, etc. On the other hand, parents that chose private subsidized schools, even if they do not consider data and performance (SIMCE) as being central to their choice, seem to lean more towards consuming educational services, looking actively for alternative educational services, "window-shopping" schools, and bringing private subsidized schools into the family option pool, all of which tells us of a certain alignment with the logic of participation as a consumer as framed by Friedman's (1955) market-driven theory. 


\section{Discussion: "Red light" on the dominant neoliberal approach to parent participation}

We conclude that currently the prevailing mode of parental participation in Chilean educational policies is as consumers of education, borne within a neo-liberal conception of education and within the framework of globalization.

The voucher system institutionalized in Chile has emphasized one particular type of practice which is the fruit of the neoliberal view of parent participation: parental choice of schools, based on informed knowledge about the quality of schools. The underlying assumptions are that school quality can be only be measured by the national SIMCE test; that schools must compete with each other under the same conditions, independent of the student's socio-economic background; that parents are not well-informed about the quality of their School i.e. SIMCE scores, and that therefore they are not making good decisions; and that, had they been well-informed, they would have chosen rationally; and finally that the most significant role of parents is to participate as consumers of education.

We conclude that all of these assumptions are questionable in the Chilean context. The rationality of school choice as a rational behavior based on school performance seems unwarranted. Parents are, indeed, choosing schools, but not based mainly on achievement outcomes. For middle and higher-income families, social status plays a key role. For medium-low and low SES families, practical reasons such as proximity play an important part, together with social-affective bonds with the school and the school staff, for deciding to stay in public municipal schools. Parents that decide to move their children from a public municipal school to a private-subsidized school seem to be doing it because they perceive a "slow rhythm" and a detrimental school climate. These are more subjective, socially-laden perceptions of "school quality".

Since parents' decisions are not only based on information about tests' scores but also on other elements which together mediate the choice, such as values, familiarity, social status, etc., one of the effects of parental school choice has been the reinforcement of school segregation and stratification. This is due to several reasons. First, as we have shown, many times it is not parents that choose schools, but quite the other way around: private and private-subsidized schools generate stringent selection processes that select families based on family income, educational history, and cultural background, and only after that has been taken care of, they select students based on academic achievement. This leaves public municipal schools with the pool of students and families "unwanted" by the other types of schools. Second, it seems that the decision underlying school choice is strongly influenced by social status and by the "peer effect", that is, the consequences of studying alongside peers of equal or higher SES. Parents seem not to be choosing schools based on school achievement. Rather, they are choosing classmates based on social status.

By strengthening educational segregation, this has deepened the already existing educational gap between the three different types of school. In this scenario, parental school choice, rationally or not, has helped to validate and reinforce the logic of school segregation. During the last 25 years, enrollment in private-subsidized schools has grown significantly 
and progressively, and enrollment in public municipal schools has declined steadily. The Chilean Observatory of Educational Policies (2006) observes that:

"In practice, private-subsidized education has operated by attracting the best students from the municipal sector ("the cream"), and inversely, "wiping off" those students who are most difficult to educate, which is generally associated with poorer socio-educational conditions of their families. As a result, those students with greater needs and/or socio-educational problems have tended to concentrate in municipal schools, which paradoxically have fewer resources" (OPECH, 2006).

Even if school choice did follow a rational, academic-based scheme, which we pose it doesn't, this form of participation constrains and impoverishes parent participation in education. In this chapter, we have shown how, in Chile, the "parents are consumers" metaphor has prevailed over the "parents are citizens" or the "parents are agents of change" paradigms. Underlying the predominance of the parents-as-consumers perspective is the logic of neoliberalism. Therefore, from the analysis of the different forms and modes of parent participation in Chile deployed during the last three decades, we conclude that the neoliberal logic is prevailing, at least in terms of parent participation.

It is necessary to recognize how problematic it is to consider parents' participation mainly as consumers of education over other ways to participate and be involved in educational process. When neoliberal policies are introduced in an educational system, certain discourses of participation over which relationship and subjectivities are constructed get also introduced. As Anderson (2001) points out,

"It is important to understand the fundamental differences between participation as consumerism and participation as citizenship. While metaphors are useful in that they tell how something is like and unlike something else, educators too often lose sight of the metaphorical use of certain terms. It has become fashionable for educational administrators and teachers to refer to their students and communities as their customers without stipulating the ways students and communities are like customers, as well as the ways students and communities are not like customers" (p. 584).

Most importantly, the logic of neoliberalism as it applies to parent participation within the voucher system, creates a social imagery that this the most important (and sole) form of parent participation, leaving out other forms of participation. Therefore, a very impoverished conception of parent participation is prevailing. As we have shown, the "Chilean way" to parent participation started out, in the early 1990s promoting different modes and forms of parent participation that framed different underlying logics of education, such as the -reconstitution of parent associations, the constitution of Unions of Parent Associations; and at the beginning of this century, the emergence of school councils. In Bahktian terms, these forms were a more heteroglosic invitation to parents. However, the first democratically elected right-wing government has installed a very monologic view on parent participation. It is expected that this narrow view on parent participation as school choice will further affect public municipal school enrollment decline and in turn favor private-subsidized school enrollment, since the logic that has long been installed is one where "private is better".

Therefore, one venue for further research is the relationship between educational policy and the types of parental participation prescribed and installed. As Anderson (2001) points out, 
participatory policies entail certain notions about subjects and relationships, and will have pragmatic effects by promoting certain values and minimizing others. Given that in Chile context is tainted by a market-driven educational model, it is interesting to see how policies containing participation discourses aligned with this model. The "Traffic-Light Map" is a clear example of such a policy. However, it received a lot of criticism, both for not offering contextual comparative data and for stigmatizing red-dotted schools and certain communes where only red dots appeared or where no green dots appeared. Parents naturally asked themselves and later complained in the media, "What I am supposed to do, change neighborhood"? Perhaps these types of critics explain why the "Traffic-Light Map" and letter was only handed in the first year of President Piñera's presidency. However, the map per commune is still available at http://www.simce.cl/mapas/index.php

Another venue for research are the challenges faced today by the other modes of parent participation - collective and organized vs. individual; representative vs. participatory-. Though scarce, data shows that parent associations reveal serious issues of real inclusion and participation at the institutional level, where hierarchical practices and parental participation in decision making is restricted, downgrading their value. At this level, it is rather an institutionalized way of restraining and limiting the organized participation of parents. Even though the policies of parent participation in the 1990s promoted more democratic forms of participation, the Chilean history of school participation, together with the hierarchical structure of the schools in Chile and the focus of policies for parent participation through school choice implemented in the early late 2000s have not favored the use of these spaces for parent participation in a more democratic and fruitful manner during the last decade.

School councils, on the other hand, are considered in many cases stale, merely formal government organs. However, schools where an environment of trust and confidence in democratic participation are already installed, they do seem to be having a positive effect in terms of the logic of citizenry. There is practically no research available as to the transformational logic of parent participation; as an example, parents participated alongside students in the Student Movement of 2011, where students marched for a "public, free, and quality education" and took over school buildings for months. Although, as we have shown, as much at the State level as organically and culturally, school related organizations incorporate neoliberal values and criteria of the understanding of education, yielding an extremely difficult landscape for parental participation in the Chilean educational system. Nonetheless these other practices are needed and research can help make them visible.

The dominant neoliberal approach to parent participation that we pose in this chapter emerges from the dynamic interaction between policies, school micropolitics and the subjective processes of parents, who themselves buy in to market-driven criteria. The studies portrayed in this chapter reveal that, although the current "Ministry voice" is quite monologic supporting parents as consumers, parents behavior is heterogeneous and heteroglosic. On one side, the logic of neoliberalism which subjectifies parents as consumers seems to work: parents are, indeed, choosing schools. The question is, for whom? for what reasons? serving whose purpose? On the other hand, parents are also participating as members of the Parent Associations and Unions of Parent Associations; as parent 
representatives in the School Councils; as supporters of the Student Movement, etc. These different patterns reveal the different discourses across parents; their actions speak louder than their words. Although they do choose schools, their actions are not limited to this domain. They are willing to engage in and do seek other forms and modes of participation. We should take a closer look at these.

\section{Author details}

Verónica López ${ }^{1,2}$, Romina Madrid ${ }^{3}$ and Vicente Sisto ${ }^{1,2}$

${ }^{1}$ Pontificia Universidad Católica de Valparaíso, School of Psychology, Chile

${ }^{2}$ Centro de Investigación Avanzada en Educación, Chile

${ }^{3}$ Doctoral student at the College of Education \& Human Development, University of Minnesota, United States.

\section{Acknowlegdments}

We thank Adolfo López for the English editing of this chapter.

\section{References}

Abrams, L. S., \& Gibbs, J. T. (2002). Disrupting the logic of home-school relations: Parent involvement strategies and practices of inclusion and exclusion. Urban Education, 37(3), 384-407.

Anderson, G.L. (2001). Hacia una participación auténtica: Deconstruyendo los discursos de las reformas participativas en educación. In Narodowski, Mariano; Nores, Milagros \& Andrada, Myrian (Eds.), Nuevas tendencias en políticas educativas. Buenos Aires: Temas/Fundación Gobierno \& Sociedad.

Apple, M. (2004). Creating difference: Neo-liberalism, neo-conservativism and the politics of educational reform. Educational Policy, 18(1), 12-44.

Apple, M. (Ed.) (2010). Global crises, social justice, and education. New York: Routledge

Ávila, P \& Reca, I. (1998). Escuela y Familia. Una Revisión del Estado del Arte. Programa P-900, División de Educación General, Ministerio de Educación, Santiago de Chile.

Barber, B. (1984). Strong democracy: Participatory politics for a new age. Berkeley, CA: University of California Press.

Barber, B. (1992). An aristocracy of everyone: The politics of education and the future of America. New York: Ballantine Books.

Bartlett, L., Frederick, M., Gulbrandsen, T., \& Murillo, E. (2002). The Marketization of Education: Public Schools for Private End. Anthropology E Education Quarterly 33(1), 5-29.

Bellei, C., Muñoz, G, Pérez, L.M., \& Raczynski, D. (2004). ¿Quién dijo que no se puede?: Escuelas Efectivas en Sectores de Pobreza. Santiago: UNICEF - Ministerio de Educación.

Bellei, C. (2007). Expansion of private schools and educational improvement in Chile. An evidence-based evaluation. Revista Pensamiento Educativo, 40(1), p. 1 - 21.

Bellei, C. Gubbins, V \& Lopez, V. (2002). Participación de los centros de padres en la educación. Expectativas, demandas, desafíos y compromisos. Ministerio de Educación, CIDE, UNICEF. 
Billig, M. (1996). Arguing and thinking. Second Edition. Cambridge: Cambridge University Press.

Bourdieu, P. \& Passeron, J. C. (1970). La Reproduction. Éléments pour une théorie du système d'enseignement avec Jean-Claude Passeron, La reproduction. Éléments d'une théorie du système d'enseignement. Paris: Les Éditions de Minuit.

Byrk, A. S., \& Schneider, B. (2002). Trust in Schools. New York: Russell Sage Foundation.

Contreras, D., \& Elacqua, G. (2006). The Effectiveness of Private School Franchises in Chile's National Voucher Program. Fotocopiado, Departamento de Economía, Universidad de Chile.

Córdova, C. (2007). Elección de escuelas en sectores pobres de Chile. (Tesis doctoral no publicada) Departamento sociología, Facultad de Educación Universidad Complutense de Madrid. Texto preliminar.

Cox, C. (comp.) (2004). Políticas educacionales en el cambio de siglo. La reforma del sistema escolar de Chile. Santiago: Editorial Universitaria.

CRECE (2009). Diagnóstico de la percepción de la comunidad educativa respecto a la educación municipal de una comuna rural de la VI región. Valparaíso, V región.

CRECE (2010). Razones de elección de establecimientos en escuelas municipalizadas de una comuna de la V región. Un estudio exploratorio.

Valparaíso, $\mathrm{V}$ región.

Dabas, E. (2000). Compartiendo territorios: Relaciones familia - escuela. Versión modificada del capítulo publicado en E. Dabas (Ed.), Viviendo Redes: Experiencias y Estrategias para fortalecer la trama social (pp.94-101). Buenos Aires: Ediciones CICCUS.

De la Fuente L. \& Raczynski, D. (2010). Estudio de evaluación de la situación de los consejos escolares: Informe Final. Santiago: Asesorías para el Desarrollo.

Dewey, J. (1927). The public and its problems. Athens, OH: Swallow Press.

Elacqua, G. \& Fábrega, R. (2004). El consumidor de la Educación. El actor olvidado de la libre elección de escuelas en Chile. Investigación patrocinada por PREAL. Universidad Adolfo Ibáñez, Santiago de Chile.

Elacqua, G. (2004). Información y libre elección en educación. Expansiva. En foco, 25, 1 - 14.

Elacqua, G. (2012). The impact of school choice and public policy on segregation: Evidence from Chile. International Journal of Educational Development, 32, 444-453.

Epstein, J.L. (2001). School, Family and Community Partnerships. Boulder, Colorado, Westview Press.

Fan, X., \& Chen, M. (2001).Parental involvement and students' academic achievement: A meta-analysis. Educational Psychology Review, 13(1), 1-22.

Fernández-Soria, J. M. (1996). Descentralización y participación de lso padres y madres en el sistema educativo. In M. Pereyra, J. Mínguez, A. Gómez \& M. Beas (Comps.), Globalización y descentralización de los sistemas educativos: Fundamentos para un Nuevo programa de la educación comparada (pp. 289-322). Barcelona: Pomaires-Corredor.

Fischer, R., González, P. \& Serra, P. (2006). Does competition in privatized social services work? The Chilean experience. World Development, 34(84), 647-664.

Flamey, G., Gubbins, V., \& Morales, F. (1999). Los centros de padres y apoderados: Nuevos actores en el control de la gestión escolar. CIDE. Santiago.

Freire, P. (1963). Alfabetização e conscientização. Porto Alegre: Editora Emma.

Friedman, M. (1955). The Role of Government in Education. En Economics of the Public Interest, ed. R.A. Solo. New Brunswick, N.J.:Rutgers University Press. 
Friedman, M. (1962). Capitalism and freedom. Chicago, IL: University of Chicago Press.

Gallego, F. \& Hernando, A. (2008). On the Determinants and Implications of School Choice: Semi-Structural Simulations for Chile. Economía. The Journal of the Latin American and the Caribbean Economic Association, 9(1), 197-244.

Garcia-Huidobro, J.E. (2007). Desigualdad educativa y segmentación del sistema escolar. Consideraciones a partir del caso chileno. Revista Pensamiento Educativo, 40(1), 65-85.

Gómez, D., Chumacera, R., \& Paredes, R. (2008). I would walk 500 miles (if paid). (Documento de Trabajo. Departamento de Ingeniería Industrial, Universidad Católica de Chile) Extraído de http://mpra.ub.uni-muenchen.de/15125/1/MPRA_paper_15125.pdf

Gordon, V., \& Nocon, H. (2008). Reproducing Segregation: Parent Involvement, Diversity, and School Governance. Journal of Latinos and Education, 7(4), 320 -339.

Guzmán, A., Hojman, V. \& López, V. (2001). Uniones Comunales de Centros de Padres y Apoderados: Una aproximación a su formación y desarrollo. En C. Bellei, V. Gubbins \& V. López (Eds.), Participación de los Centros de Padres en la Educación (pp. 49-65). Santiago de Chile: UNICEF.

Hoxby, C. (2002). Would school choice change the teaching profession?. Journal of Human Resources 37, 846-891.

Hoxby, C., M. (2001). Rising Tide: New Evidence on Competition and the Public Schools. Education Next, 4, 68-74.

Hsieh, C., \& Urquiola, M. (2006). The effects of generalized school choice on achievement and stratification: Evidence from Chile's voucher program. Journal of Public Economics, 90, 1477- 1503.

Ibáñez, T., \& Iñiguez, L. (1996). Aspectos metodológicos de la psicología social aplicada. In J. L. Alvaro, J. R. Torregrosa, \& A. Garrido (Eds.). Psicología social aplicada. Madrid: McGraw-.

Iñiguez, L., \& Antaki, Ch. (1994). El análisis del discurso en psicología social. Boletín de Psicología, 44, 57-75.

Kahne, J. (1994). Democratic communities, equity, and excellence: A Deweyan reframing of educational policy analysis. Educational Evaluation and Policy Analysis, 16(3), 233-248.

Lareau, A. (2003). Uneqal Childhoods: Class, race, and Family Life. Berkeley, CA: University of California Press.

Martinello, M. (1999). Participación de los Padres en la Educación: Hacia una Taxonomía para América Latina. Development Discussion Papers, 709. Harvard University: Harvard Institute for International Development.

Martinic, S. (2002). Participación y Calidad Educativa. Serie Expansiva. En Foco, número 82.

Mayo, P. (2004). Liberating Praxis. Paulo Freire's Legacy for Radical Education and Politics. Westport, CO: Praege.

McLaren, P. (2000). Che Guevara, Paulo Freire and the Pedagogy of Revolution. Maryland: Rowman \& Littlefield.

McLaren, P., \& Lankshear, C. (Eds.) (1994). Politics of Liberation. Paths from Freire. New York: Routledge.

Morrow, R. A., \& Torres, C. A. (2002). Reading Freire and Habermas. Critical pedagogy and Transformative Social Change. New York: Teachers College Press.

Ministerio de Educación. (2002). Política de Participación de Padres, Madres y Apoderados/as en el Sistema Educativo. Ministerio de Educación. División de Educación General. Unidad de Apoyo a la Transversalidad. Santiago, Chile. 
Ministerio de Educación. (2011). Institucionalidad de la educación en Chile. Santiago, Chile: Ministerio de Educación.

Ministerio de Educación. (2012). Resultados destacados SIMCE 2011. Available at http://datastorage.mineduc.cl/consultasimce/simce/Resultados_Nacionales_SIMCE2011.pdf

Ministerio de Educación/CIDE/UNICEF. (2005): Participación de los Centros de Padres en la Educación: Ideas y Herramientas para mejorar la organización. Ministerio de Educación, CIDE, UNICEF (2da. Edición)

Mizala, A \& Romaguera, P. (2000). School performance and choice: the Chilean experience. Journal of Human Resources, 35 (2), 392-417

Mizala, A., Romaguera, P., \& Urquiola, M. (2007). Socioeconomic status or noise? Tradeoffs in the generation of school quality information. Journal of Development Economics, 84, 61-75.

Montecinos, C., Sisto, V., \& Ahumada, L. (2010). The construction of parents and teachers as agents for the improvement of municipal schools in Chile. Comparative Education, 46(4), 487 - 508. doi: 10.1080/03050068.2010.519481

Neal, D. (2002). How Vouchers Could Change the Market for Education. Journal of Economic Perspectives, 16(4), 25-44.

Olssen, M., \& Peters, M. A. (2005). Neoliberalism, higher education and the knowledge economy: From the free market to knowledge capitalism. Journal of Education Policy, 20(3), 313-345.

Observatorio Chileno de Políticas Educativas (OPECH). (2006). Ley subvención escolar preferencial?: Notas para la discusión. Documento de Trabajo $\mathrm{N}^{\circ} 2$. "El derecho ciudadano a participar en la educación pública".

OECD. (2004). Revisión de las políticas nacionales de educación: Chile. Paris: Organización para la cooperación y el desarrollo.

Plank, D. \& Sykes, G. (2003). Why School Choice?. En Plank, D. y G. Sykes (Eds.), Choosing Choice: School Choice in International Perspective. New York \& London: Teachers College Press.

Potter, J., \& Wetherell, M. (1987). Discourse and social psychology. London: Sage.

Reca, I. \& López, V. (2001). La participación organizada de los padres en la educación. Cuadernos Sociológicos, 1, 51-82.

Reca, I. \& López, V. (2002). Experiencias Internacionales de Participación Organizada de los Padres y Madres en la Educación: Reflexiones para Chile. In C. Bellei, V. Gubbins \& V. López (Eds)., Participación de los centros de padres en la educación. Expectativas, demandas, desafíos y compromisos. Santiago: UNICEF.

Reimers, F., \& McGinn, N. (2000). Dialogo informado: el uso de la información para conformar la política educativa. Mexico: Centro de Estudios Educativos AUSJAL.

Schneider, M., Elacqua, G., \& Buckley, J. (2006). School choice in Chile: Is it class or the classroom? Journal of Policy Analysis and Management, 25(3), 577-601.

Sisto, V. (2011). Nuevo profesionalismo y profesores: una reflexión a partir del análisis de las actuales políticas de 'profesionalización' para la educación en Chile. Signo y Pensamiento 31 (59), 178-192.

Taut, S., Cortés, F., Sebastian, C., \& Preiss, D. (2009). Evaluating school and parent reports of the national student achievement testing system (SIMCE) in Chile: Access, comprehension, and use. Evaluation and Program Planning, 32, 129-137.

Wetherell, M., Taylor, S., \& Yates, S. (2001). Discourse as data: A guide for analysis. London: Sage. 